The Free Internet Journal

for Organic Chemistry
Paper

Arkivoc 2017, part vii, 0-0 to be inserted by editorial office

\title{
Synthesis of 4-alkoxypyridines as intermediates for zwitterionic liquid crystals
}

\author{
Anas N. Hajhussein, ${ }^{a}$ Loay S. Abuzahra, ${ }^{a}$ Anna Pietrzak,,${ }^{a, b}$ Mary F. Sadek, ${ }^{a}$ Muhammad O. Ali, ${ }^{a}$ Jakub \\ Wojciechowski, a Andrienne C. Friedli, * a and Piotr Kaszyński*a,c,d \\ ${ }^{a}$ Organic Materials Research Group, Department of Chemistry, Middle Tennessee State University, \\ Murfreesboro, TN 37132, USA \\ ${ }^{b}$ Łódź University of Technology, 90924 Łódź, Poland \\ ' Centre of Molecular and Macromolecular Studies, Polish Academy of Sciences, 90-363 Łódź, Poland \\ ${ }^{d}$ Faculty of Chemistry, University of Łódź, 91403 Łódź, Poland \\ Email: Piotr.kaszynski@mtsu.edu
}

\section{Abstract}

A series of 4-alkoxypyridines with $n=5-18$ was obtained in typical yields of $75-80 \%$ by reacting 4 -chloropyridine hydrochloride with the appropriate alcohol in DMSO in the presence of powdered $\mathrm{NaOH}$. The reported synthesis is compared to other methods for preparation of 4-alkoxypyridines, and their uses are reviewed. 4-Tridecyloxypyridine is converted into the bis-zwitterionic derivative of $\left[\text { closo- } \mathrm{B}_{10} \mathrm{H}_{10}\right]^{2-}$, which exhibits liquid crystalline and soft crystalline phases. The solid-state structures of two pyridines and the biszwitterion are established by the single crystal XRD method. The effect of $N$-atom coordination on the pyridine ring geometry is investigated.

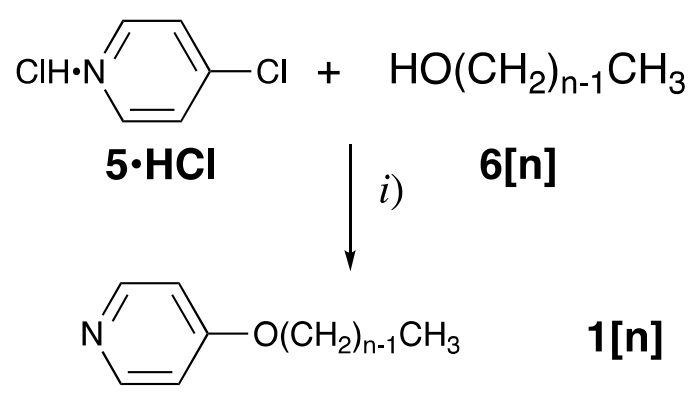

Keywords: Pyridines, XRD, closo-borane, zwitterions, liquid crystals 


\section{Introduction}

There is a rapidly growing interest in 4-alkoxypyridines $1[n](n \geq 3)$ as intermediates for soft materials such as liquid crystals ${ }^{1-5}$ (including polar, ${ }^{6-11}$ ionic $^{12-15}$ and quadrupolar species, such as $2[\mathbf{n}]^{10}$ in Figure 1), molecular electronics, ${ }^{16}$ bio-active derivatives, ${ }^{17-19}$ and also for research on organometallic complexes, ${ }^{2-4,20-22}$ weak intermolecular interactions, ${ }^{1,5}$ and various other aspects of organic chemistry ${ }^{23-25}$ Some 4-alkoxypyridines $\mathbf{1}$ [n] have been shown to exhibit biological activity, such as inhibition of cytochrome P-450-catalyzed aniline hydroxylation ${ }^{26,27}$ or gastric antisecretory activity. ${ }^{28}$

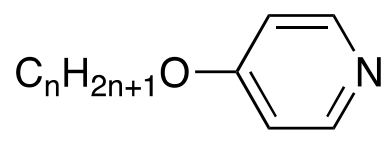

$1[n]$

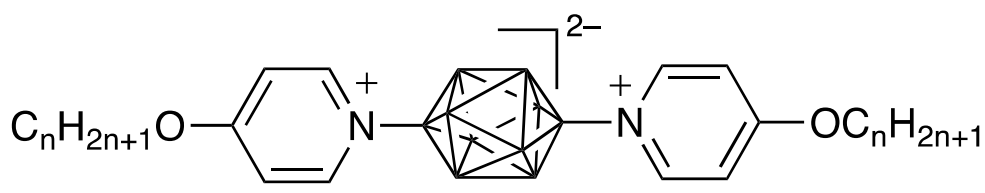

2[n]

Figure 1. Structures of $\mathbf{1}[\mathrm{n}]$ and $\mathbf{2}[\mathrm{n}]$

In most cases, 4-alkoxypyridines $(\mathbf{1}[\mathbf{n}])$ are $N$-substituted by reactions with metal-centered Lewis acids, ${ }^{2,3,20-22}$ organic electrophiles, ${ }^{12,13,18,19,23,25}$ or boron electrophiles. ${ }^{6,7,11}$ In rare cases C-positions of the pyridine ring in $\mathbf{1}\left[\mathbf{n}\right.$ ] are substituted before further transformations. ${ }^{16,24}$

In spite of the increasing use of 4-alkoxypyridines $(\mathbf{1}[\mathbf{n}] ; \mathbf{n} \geq 3)$, only a handful are well characterized $\left(\mathbf{1}[\mathbf{3}],{ }^{29,30} \mathbf{1}[\mathbf{7}],{ }^{6,7} \mathbf{1}[\mathbf{8}],{ }^{5,23} \mathbf{1}[\mathbf{9}],{ }^{7} \mathbf{1}[\mathbf{1 0}],{ }^{1,16} \mathbf{1}[\mathbf{1 2}],{ }^{5} \mathbf{1}[\mathbf{1 6}]^{5}\right)$, some have partial data $\left(\mathbf{1}[\mathbf{4}],{ }^{19,24,28} \mathbf{1}[5],{ }^{7,28} \mathbf{1}[\mathbf{8}]^{23}\right.$, $\left.\mathbf{1}[\mathbf{1 6}]^{4}\right)$, while others are only mentioned in the literature without any data $\left.(\mathbf{1}[6]),{ }^{20,27} \mathbf{1}[\mathbf{1 4}],,^{12} \mathbf{1}[\mathbf{1 8}]^{12,22}\right)$ and several homologs are not reported (e.g. 1[11], 1[13] and 1[15]). Therefore, there is a need for a comprehensive approach to the synthesis of this series $\mathbf{1}[\mathbf{n}]$ and complete characterization of its members.

The reported methods for synthesis of $\mathbf{1}[\mathrm{n}$ ] can be divided into two general categories: those using alkyl electrophiles and pyridine nucleophiles (Method A, Figure 2) and those using alkyl nucleophiles and pyridine electrophiles (Method B, Figure 2). In the first method, the most convenient pyridine precursor is 4hydroxypyridine (3) (4-pyridone), which is deprotonated with a base and reacted with an alkyl halide 4[n]. Due to the amphiphilic nature of the anion generated from 3, a mixture of two isomeric products is formed, then separated by chromatography. This can be tedious and difficult for higher homologs. The method is relatively inexpensive and simple, but the ratio of the two isomers of the $\mathrm{N}-\mathrm{vs} \mathrm{O}$-alkylated product depends on the reaction conditions. Thus, when the reaction is conducted with $\mathrm{K}_{2} \mathrm{CO}_{3}$ in DMF at ambient temperature, $1[10]$ is obtained in $70 \%$ yield, ${ }^{1} \mathbf{1}[16]$ in $89 \%$ yield, ${ }^{3}$ and also 1 [12] was obtained under these conditions. ${ }^{21}$ On the other hand, in MeCN solutions at reflux, the yield of 1 [12] was only $9 \% .{ }^{31}$ The same reaction conducted in a THF/aq $\mathrm{NaOH}$ system with $\left[\mathrm{Bu}_{4} \mathrm{~N}\right]^{+} \mathrm{Br}^{-}$as a phase transfer catalyst gave the $\mathrm{N}$-alkylated products isolated in yields $75-80 \% .^{12}$

Method $B$ involves electrophilic pyridine derivatives with a leaving group at the $\mathrm{C}(4)$ position. The most useful reagent is 4-chloropyridine (5) or its hydrochloride $(5 \cdot \mathbf{H C l})$, available from 4-hydroxypyridine (3). The alkoxide nucleophile is generated from the appropriate alcohol 6[n] typically by using $\mathrm{Na}^{22,25,29} \mathrm{or} \mathrm{NaH}^{24}$ in excess alcohol as the solvent (typically in lower boiling alcohols, but also $\mathbf{1}[\mathbf{1 0}]^{25}$ and $\mathbf{1}[\mathbf{1 8}]^{22}$ were obtained this way) or with $\mathrm{NaH}$ in dry DMSO. ${ }^{5-7,23}$ There are also two reports of using $\mathrm{NaOH}$ in DMSO to generate the 
alkoxide, but with no details provided. ${ }^{12,18}$ In another modification, 4-chloropyridine (5) or 4-bromopyridine is reacted with excess propanol (6[3]), $\mathrm{K}_{2} \mathrm{CO}_{3}$ and catalytic amounts of $\mathrm{Zn}\left(\mathrm{NO}_{3}\right)_{2} \cdot 6 \mathrm{H}_{2} \mathrm{O}$ at $75{ }^{\circ} \mathrm{C}$ for 24 hours giving 1[3] in $84 \%$ yield. $^{30}$ In some earlier literature, $N$-(pyrid-4-yl)pyridinium hydrochloride ${ }^{19}$ and 4phenoxypyridine ${ }^{32,33}$ were reacted with RONa in excess alcohol to obtain some $\mathbf{1}[\mathbf{n}]$.

One main advantage of the method described here is the clean formation of a single product, the desired 4-alkoxypyridine $(\mathbf{1}[\mathbf{n}])$, which simplifies its isolation. The method can be more practical and less expensive without anhydrous conditions and using a less expensive base to generate the alkoxide.

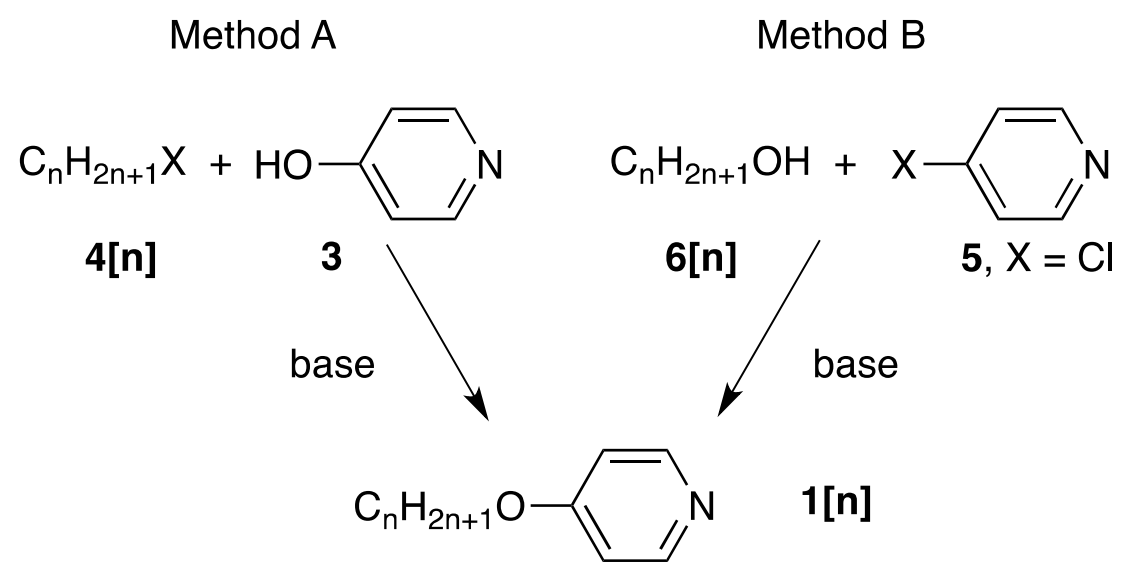

Figure 2. Two general methods for synthesis of 4-alkoxypyridines (1[n]).

Here we report the preparation of 12 members of a homologous series $\mathbf{1}[\mathbf{n}](n=5-18$, Figure 2 ) using a modified method $\mathrm{B}$ in which powdered $\mathrm{NaOH}$ is used in reagent grade DMSO. All derivatives were completely characterized including two new 4-alkoxypyridines, 1[11] and 1[13]. We demonstrate application of the pyridines by preparing a bis-zwitteronic derivative 2[13]. We also report three molecular structures obtained by single crystal XRD methods.

\section{Results and Discussion}

\section{Synthesis}

A series of 4-alkoxypyridines $\mathbf{1}[\mathrm{n}](n=5-18)$ was obtained from 4-chloropyridine hydrochloride $(5 \cdot \mathbf{H C l})$ and appropriate alcohol 6[n] in reagent grade DMSO (not dried) in the presence of finely divided $\mathrm{NaOH}$ (powder or sand, Scheme 1). The products were separated from the unreacted alcohol by short-path distillation $(n \leq 9)$, Kugel-Rohr distillation ( $n=10-12$ ) or column chromatographic separation for higher members of the series. The typical isolated yields for $\mathbf{1}[\mathbf{n}$ ] under the optimized conditions were in the range $75-80 \%$ based on the alcohol. 


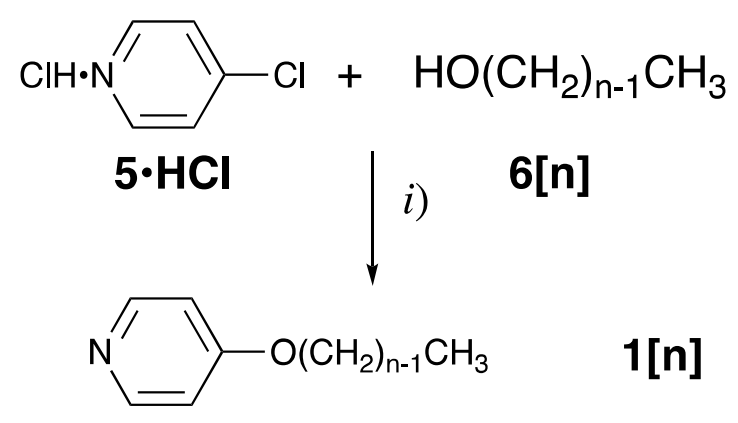

Scheme 1. Synthesis of derivatives 1 [n]. Reagents and conditions: i) $\mathrm{NaOH}$ powder or sand, $4-\mathrm{ClC} \mathrm{C}_{5} \mathrm{~N} \cdot \mathrm{HCl}$ $(5 \cdot \mathrm{HCl}), \mathrm{ROH}(6[\mathrm{n}]), \mathrm{DMSO}, 80^{\circ} \mathrm{C}, 16 \mathrm{~h}$.

Reaction conditions were optimized using $5 \cdot \mathbf{H C l}$ and nonanol (6[9]) on 5 or $10 \mathrm{mmol}$ scale in $10 \mathrm{or} 20 \mathrm{~mL}$ of DMSO. Initial experiments demonstrated that for stoichiometric amounts of reagents (1:1 ratio) and excess base, significant amounts of alcohol 6[n] (20-30\%) were unconsumed. This complicated separation of pure $\mathbf{1}[\mathrm{n}$ ], especially for higher members of the series for which differences in the properties diminish with $\mathrm{n}$. Therefore, it was decided to use excess $5 \cdot \mathbf{H C l}$, which can be easily removed from the product either by aqueous work-up or by evaporation (as free base). It was established that full or nearly complete conversion $(\geq 98 \%$ ) of the alcohol requires $20 \%$ excess $5 \cdot \mathbf{H C l}$ added in two portions: 1.0 equiv at the beginning and 0.2 equiv after $0.5 \mathrm{~h}$ or later. Although for lower alcohols such as octanol the procedure is not economical due to the relatively high cost of $\mathbf{5} \cdot \mathbf{H C l}$, it might be efficient for rare alcohols, such as optically active citronellol.

Experiments with various amounts of $\mathrm{NaOH}$ demonstrated that at least three equivalents per one equivalent of the alcohol is required and five equivalents is optimum for the reaction to be completed overnight at $80^{\circ} \mathrm{C}$. Monitoring progress of these test reactions with stoichiometric amounts of reagents $(4 \cdot \mathbf{H C l}$ : 6[9]: $\mathrm{NaOH}, 1: 1: 5)$ with ${ }^{1} \mathrm{H}$ NMR spectroscopy demonstrated that within the first hour about 33\% of $\mathbf{1}[9]$ is formed, which increases to $71 \%$ after an additional $2 \mathrm{~h}$, but does not change significantly overnight.

Finally, the effect of temperature on reaction progress and the yield of the product were also briefly investigated using the ${ }^{1} \mathrm{H} N M R$ of the crude reaction mixture stirred overnight. For the test reaction $(\mathbf{5} \cdot \mathbf{H C l}$ : 6[9]: $\mathrm{NaOH}, 1: 1: 5)$, the yield of $\mathbf{1}$ [n] or degree of conversion of 1-nonanol (6[9]), was $71 \%$ at $80{ }^{\circ} \mathrm{C}, 62 \%$ at 100 ${ }^{\circ} \mathrm{C}$ and only $43 \%$ at $120{ }^{\circ} \mathrm{C}$. This suggests chemical instability of the pyridine ring under highly caustic conditions at elevated temperatures. On the other hand, below $80^{\circ} \mathrm{C}$ the reaction proceeded very slowly.

The obtained pyridines $\mathbf{1}[\mathbf{n}$ ] have been used for the preparation of zwitterionic derivatives of closoboranes. ${ }^{7,10}$ An example of such a synthesis is shown in Scheme 2. Thus, stirring of bis-phenyliodonium derivative 7 with excess pyridine 1[13] used as the solvent at $80{ }^{\circ} \mathrm{C}$ led to bis-pyridinium derivative 2[13] isolated by column chromatography in $51 \%$ yield. 


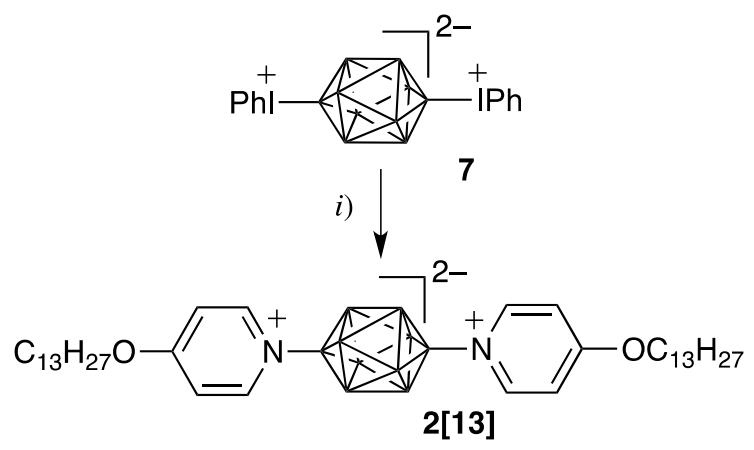

Scheme 2. Synthesis of derivative 2[13]. Reagents and conditions: i) $4-\mathrm{C}_{13} \mathrm{H}_{27} \mathrm{OC}_{5} \mathrm{H}_{4} \mathrm{~N}(\mathbf{1}[13])$ neat, $80{ }^{\circ} \mathrm{C}, 12 \mathrm{~h}$.

\section{Molecular and crystal structures}

Colorless crystals of $\mathbf{1}[\mathbf{1 3}]$ and $\mathbf{1}[\mathbf{1 6}]$ were obtained by slow evaporation of pentane solutions, while crystals of 2[13] were grown from MeCN solutions. Their solid-state structures were determined by low temperature single crystal X-ray analysis and results are shown in Figures 3-5. Data collection and refinement details are provided in the Supplentary Material. ${ }^{34}$

The pyridine derivative 1[13] forms monoclinic crystals with $P 21 / n$ space group with four molecules in the unit cell. In contrast, $\mathbf{1}[\mathbf{1 6}$ ] and $2[13]$ crystallize in a triclinic $P \overline{\mathbf{1}}$ space group with a unit cell containing two molecules, as shown in Figure 3.

The molecular dimensions in $\mathbf{1}[13]$ and $\mathbf{1}[16]$ are typical for alkoxy groups and the pyridine ring. The molecules have essentially $C_{s}$ symmetry: the alkoxy chains are in a nearly ideal all-trans conformation and coplanar with the pyridine ring (the interplanar angle between the alkoxy chain and the pyridine ring is $1.9^{\circ}$ and $2.4^{\circ}$, respectively). The total molecular length measured as the $N \cdots C(13)$ and $N \cdots C(16)$ distance is $20.26 \AA$ and $24.20 \AA$, respectively. Similar planar molecular geometry and dimensions are observed in the $\mathbf{1}[\mathbf{1 0}]$ derivative. ${ }^{35}$

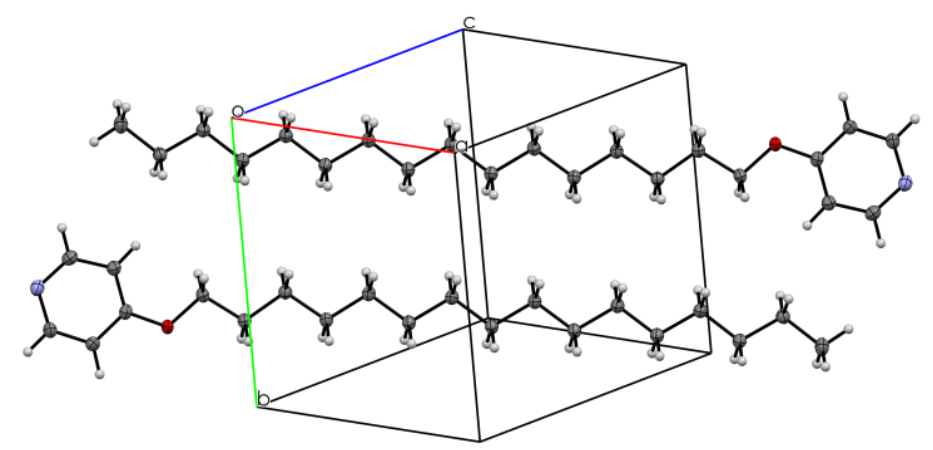

Figure 3. Unit cell packing diagram for 1[16] viewed along the ac axis. Thermal ellipsoid diagram drawn at 50\% probability and the numbering system according to the chemical structure. Pertinent molecular dimensions: $N(1)-C(2) 1.344(1) \AA, C(2)-C(3) 1.379(1) \AA, C(3)-C(4) 1.397(1) \AA, C(5)-C(6) 1.382(1) \AA, C(6)-N(1) 1.341(1) \AA$, $\mathrm{C}(4)-0$ 1.359(1) $\AA, 0-C_{\text {Alkyl }} 1.4433(9) \AA, C(4)-O-C_{\text {Alkyl }} 118.24(6)^{\circ}, C(6)-N(1)-C(2) 115.50(7)^{\circ}$.

The molecular dimensions of the bis-pyridinium derivative 2[13] are similar to those reported for its three homologues. ${ }^{10}$ In contrast to its homologues, the solid-state structure of 2[13] shows no positional disorder and the alkoxy chains are in the all-trans conformation. Crystal packing forces impose a small angle between the planes of the alkoxy chain and the pyridine ring $\left(19.7^{\circ}\right.$ and $\left.18.6^{\circ}\right)$, while the two pyridine rings are nearly 
coplanar $\left(6.8^{\circ}\right)$. Overall, molecules of 2[13] adopt an S-shape, which is similar to that found for its homologues. ${ }^{10}$

Molecules of 2[13] are closely packed in the unit cell with maximum interactions of the local B-N dipole moments (the $B(1) \cdots N$ intermolecular distance is $5.940(1) \AA$ ).

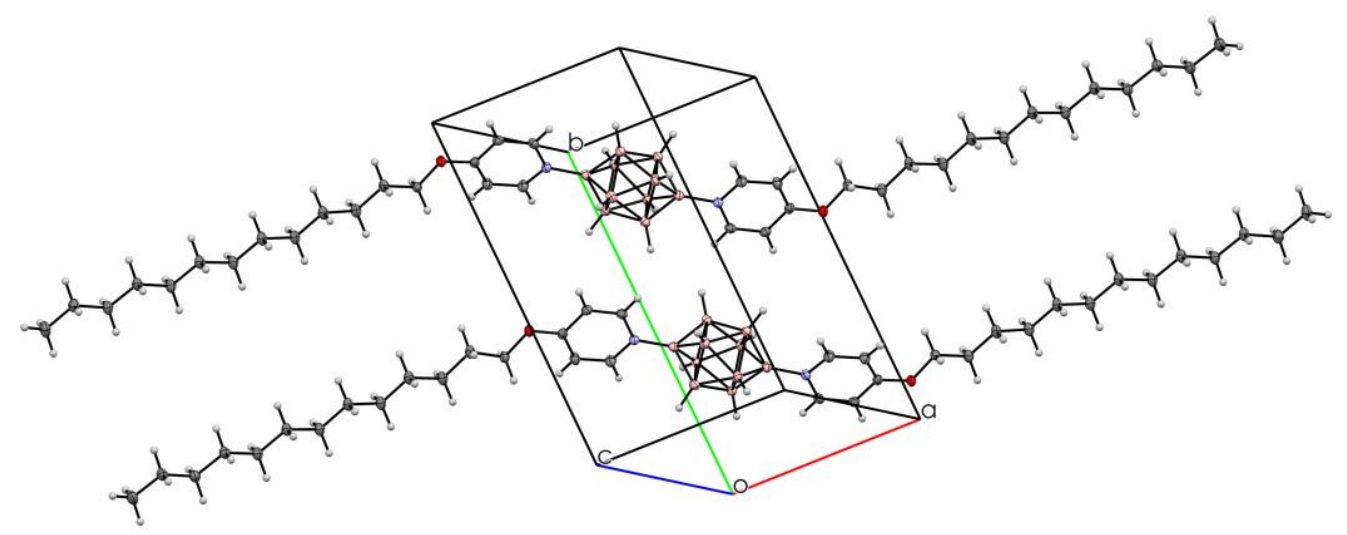

Figure 4. Unit cell packing diagram for 2[13]. Thermal ellipsoid diagram drawn at 50\% probability and the numbering system according to the chemical structure. Pertinent molecular dimensions: $B(1) \cdots B(10) 3.625(2)$ $\AA, B-N 1.526(1)$ and $1.530(1), N(1)-C(2) 1.354(2) \AA, C(2)-C(3) 1.369(1) \AA, C(3)-C(4) 1.397(1) \AA, C(4)-C(5)$ $1.397(1) \AA, C(5)-C(6) 1.373(1) \AA, C(6)-N(1) 1.349(1) \AA, C(4)-01.339(1) \AA ̊ 0-C_{\text {Alkyl }} 1.453(1) \AA, C(4)-O-C_{\text {Alkyl }}$ $117.4(1)^{\circ}, C(6)-N(1)-C(2) 118.1(1)^{\circ}$.

The availability of the molecular structures for 1 [13] and 2[13] permits the assessment of the effect of coordination of the nitrogen atom on pyridine ring geometry. Thus, the $C(2)-C(3)$ and $C(4)-O$ bonds contract by about -0.01 and $-0.02 \AA$, respectively, while other bonds expand by an average of +0.01 (Figure 5a). Also, the $\mathrm{C}-\mathrm{N}-\mathrm{C}$ angle expands by $+2.6^{\circ}$. These changes are consistent with shifting electron density from the oxygen atom towards the nitrogen atom and distortion towards a quinoid structure with localized double bonds such as in $\mathrm{N}$-alkylpyridones. ${ }^{12}$ Similar results were obtained when structure of 2[13] is compared to that of 1[16]. The observed changes in bonding parallel those in ${ }^{1} \mathrm{H}$ NMR chemical shifts, which reflect not only electron density redistribution, but also magnetic anisotropy of the ring current in the $\left\{\right.$ closo- $\left.\mathrm{B}_{10}\right\}$ cluster (Figure 5b).

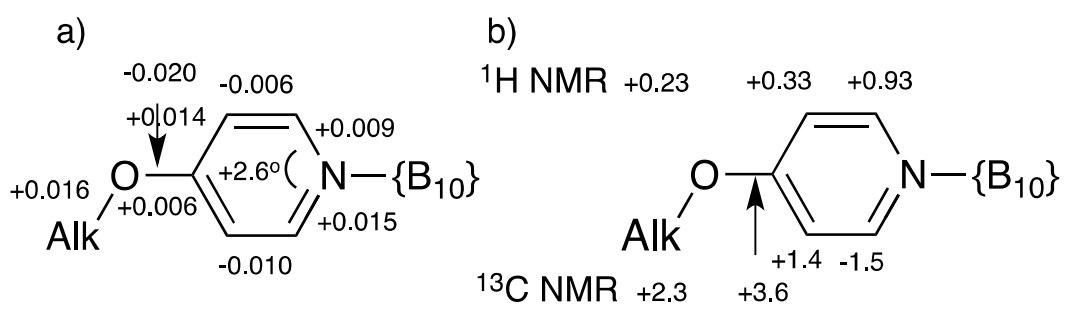

Figure 5. Effect of $N$-coordination on pyridine a) ring geometry b) NMR chemical shifts. The numbers represent the change $\mathrm{a})$ in bond lengths $(\Delta \AA)$ and in angles $\left(\Delta^{\circ}\right)$ and b) NMR shifts $(\Delta \delta)$ from 1 [13] to 2[13]. 


\section{Liquid crystalline behavior}

Thermal analysis of 2[13] revealed rich polymorphism as shown in Figure 6. Upon heating, the sample undergoes stepwise melting through four polymorphs before transitions at $160{ }^{\circ} \mathrm{C}$ to a $21 \mathrm{~K}$ wide nematic phase (Figure 7). Analysis of the cooling curve shows small hysteresis of the transitions, which suggests the formation of soft-crystalline phases. On the basis of powder XRD analysis for 2[12], ${ }^{10}$ the phase below the nematic phase can be assigned as a crystalline laminate phase, Lam $\mathrm{cr}$.

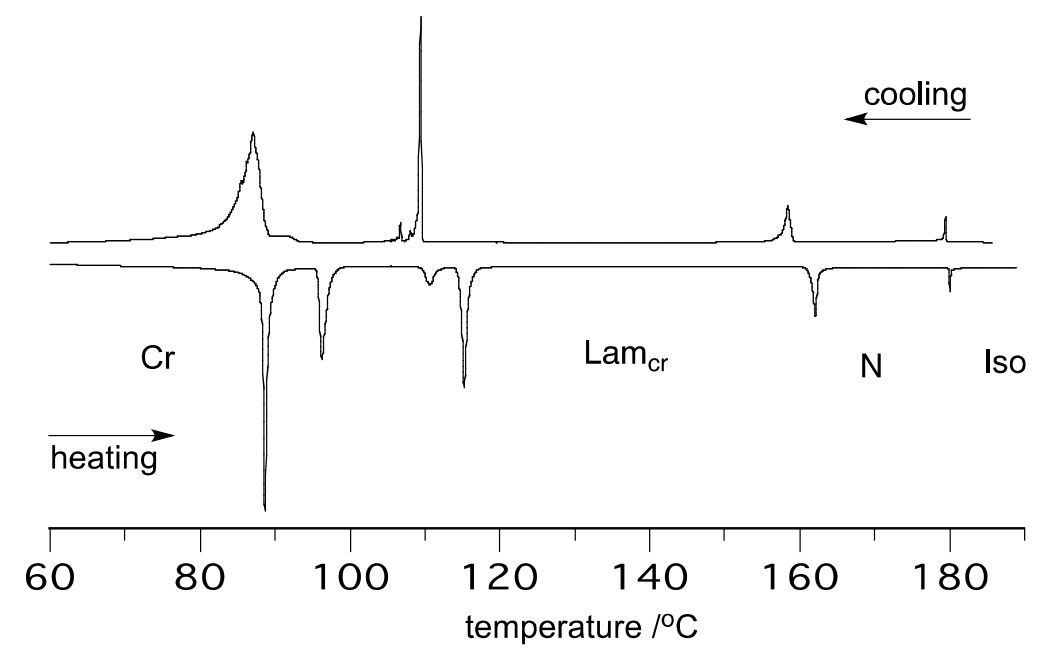

Figure 6. DSC trace of 2[13]. Transition temperatures and enthalpies (in italics): $\mathrm{Cr}_{1} 88$ (25.8) $\mathrm{Cr}_{2} 96$ (11.5) $\mathrm{Cr}_{3}$ $110(10.4) \times 115(12.7)$ Lam $\mathrm{cr} 162(4.1) \mathrm{N} 180(0.8)$ I. The heating and cooling rates are $10 \mathrm{~K} \mathrm{~min}^{-1}$.

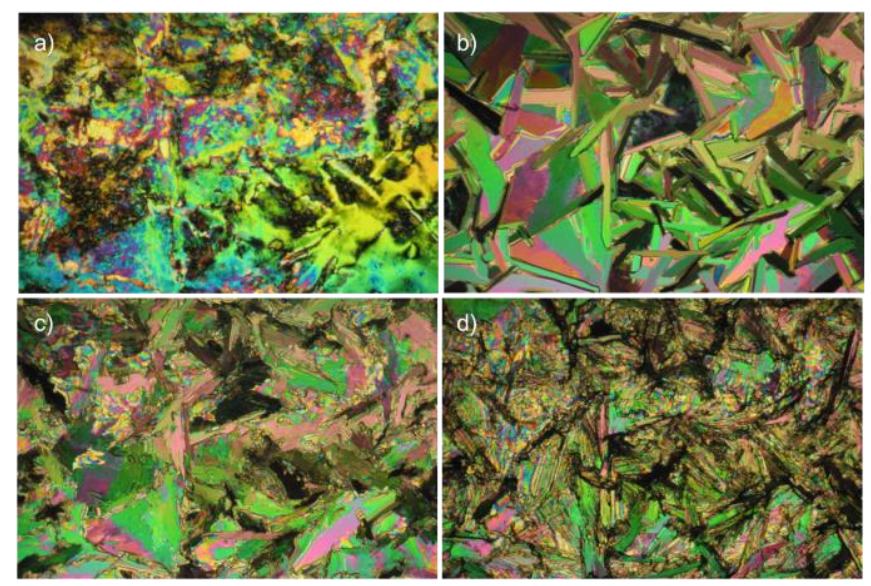

Figure 7. Optical textures in polarized light of a) nematic phase $\left(\mathrm{N}, 170{ }^{\circ} \mathrm{C}\right)$, b) lamellar crystalline phase, $\left(\right.$ Lam $\left.\left._{\mathrm{cr}}, 140{ }^{\circ} \mathrm{C}\right), \mathrm{c}\right)$ an unidentified $\mathrm{X}$ phase $\left(90^{\circ} \mathrm{C}\right)$, and $\left.\mathrm{d}\right)$ crystalline phase $\left(\mathrm{Cr}, 80^{\circ} \mathrm{C}\right)$ for 2 [13] obtained on cooling for the same sample region.

\section{Summary and Conclusions}

A simple and efficient procedure for the preparation of series of 4-alkoxypyridines $\mathbf{1}$ [n] was developed and demonstrated for 12 members of the series. Reaction conditions and isolation procedures were optimized and 
all compounds were completely characterized using NMR, IR spectroscopy and MS spectrometry. The procedure is particularly useful for high value primary alcohols. Application of the pyridines was demonstrated by preparation of $\mathbf{2}[\mathbf{1 3}]$, a new homolog of the $\mathbf{2}[\mathbf{n}$ ] series. A comparison of solid-state structures demonstrated pyridine ring geometry alteration upon coordination of the nitrogen atom.

\section{Experimental Section}

General. Reactions were carried out under $\mathrm{Ar}$ and subsequent manipulations were conducted in air. NMR spectra were obtained at $500 \mathrm{MHz}\left({ }^{1} \mathrm{H}\right), 125 \mathrm{MHz}\left({ }^{13} \mathrm{C}\right)$ and $160 \mathrm{MHz}\left({ }^{11} \mathrm{~B}\right)$ fields. Chemical shifts were referenced to the solvent $\left({ }^{1} \mathrm{H} \text { and }{ }^{13} \mathrm{C}: 7.26 \mathrm{ppm} \text { and } 77.16 \mathrm{ppm} \text { for } \mathrm{CDCl}_{3}\right)^{36}$ or to an external sample of neat $\mathrm{BF}_{3}$. EtO in $\mathrm{CDCl}_{3}$ set at $0 \mathrm{ppm}$. All reagents and solvents: 1-alkanols (6[n]), 4-chloropyridine hydrochloride $(\mathbf{5} \cdot \mathbf{H C l})$ and DMSO, were obtained from Sigma-Aldrich and used as received. Finely divided $\mathrm{NaOH}($ sand) was obtained from Loudwolf Industrial and Scientific and stored in a desiccator.

\section{General procedure for synthesis of 4-alkoxypyridines (1[n])}

A $100 \mathrm{~mL}$ round bottom flask was flushed with argon and reagents added via funnel in the following order: finely divided sodium hydroxide $(2.00 \mathrm{~g}, 50.0 \mathrm{mmol})$, alcohol $6[\mathrm{n}](10.0 \mathrm{mmol})$, and reagent grade DMSO (12 $\mathrm{mL}$ ). The mixture was heated with stirring to $80{ }^{\circ} \mathrm{C}$ under argon and 4-chloropyridine hydrochloride $(\mathbf{5} \cdot \mathbf{H C l}$, $1.50 \mathrm{~g}, 10.0 \mathrm{mmol})$ was added with DMSO rinse $(8 \mathrm{~mL})$. After approximately $30 \mathrm{~min}$, an additional portion of $\mathbf{5} \cdot \mathbf{H C l}(0.300 \mathrm{~g}, 2.0 \mathrm{mmol})$ was added. The reaction was stirred and heated overnight. Water was added (20 $\mathrm{mL})$ and the mixture was extracted with EtOAc/hexane $(1: 1,2 \times 20 \mathrm{~mL})$. The organic layer was separated, dried $\left(\mathrm{Na}_{2} \mathrm{SO}_{4}\right)$, and solvent was removed under reduced pressure. Lower members of the series $\mathbf{1}$ [n] were purified from traces of impurities and unreacted alcohol by short-path distillation $(n \leq 9)$ or Kugel-Rohr distillation ( $n=$ 10-12), while higher members of the series $\mathbf{1}[\mathbf{n}](n>12)$ were purified by column chromatography using silica gel with gradient EtOAc/hexanes mixtures (starting from 5\% up to 25\% EtOAc) as eluent. Typical yields of isolated and purified products as colorless liquids or solids are in a range $75-80 \%$. All 4-alkoxypyridines $\mathbf{1}$ [n] exhibit the following characteristic IR vibrations: (neat) $v 1595,1571,1473,1286,1216,1022,820 \mathrm{~cm}^{-1}$.

4-Tridecyloxypyridine (1[13]). Mp 34-36 ${ }^{\circ} \mathrm{C} ;{ }^{1} \mathrm{H} \mathrm{NMR}\left(500 \mathrm{MHz}, \mathrm{CDCl}_{3}\right) \delta 0.88(\mathrm{t}, J 6.9 \mathrm{~Hz}, 3 \mathrm{H}), 1.24-1.35(\mathrm{~m}$, $18 \mathrm{H}$ ), 1.45 (quint, J $7.4 \mathrm{~Hz}, 2 \mathrm{H}$ ), 1.79 (quint, J $7.2 \mathrm{~Hz}, 2 \mathrm{H}$ ), 3.99 (t, J $6.6 \mathrm{~Hz}, 2 \mathrm{H}$ ), 6.79 (dd, J $\mathrm{J}_{1} .8 \mathrm{~Hz}, J_{2} 1.5 \mathrm{~Hz}, 2 \mathrm{H}$ ), 8.40-8.42 (m, 2H). ${ }^{13} \mathrm{C}$ NMR (125 MHz, $\left.\mathrm{CDCl}_{3}\right): \delta$ 14.2, 22.8, 26.0, 28.9, 29.4, 29.4, 29.6, 29.6, 29.7 (2C), 29.7 , 32.0, 67.9, 110.3, 151.1, 165.1. Anal. Calcd. for $\mathrm{C}_{18} \mathrm{H}_{31} \mathrm{NO}$ : C, 77.92; $\mathrm{H}, 11.26 ; \mathrm{N}, 5.05$. Found: C, 77.86; $\mathrm{H}, 11.40$; N, $4.97 \%$.

Analytical data for other derivatives $1[\mathrm{n}]$ are provided in the Supporting Information.

Preparation of [closo- $\mathrm{B}_{10} \mathrm{H}_{8}-\mathbf{1}, \mathbf{1 0}-\left(\mathrm{NC}_{5} \mathrm{H}_{4} \mathrm{OC}_{13} \mathrm{H}_{17}\right)_{2}$ ] (2[13]). A mixture of [closo- $\left.\mathrm{B}_{10} \mathrm{H}_{8}-1,10-(\mathrm{IPh})_{2}\right]^{37}$ (7, $200 \mathrm{mg}$, $0.39 \mathrm{mmol}$ ) and 4-tridecyloxypyridine (1[13]), $1.5 \mathrm{~mL}$ ) was stirred at $80{ }^{\circ} \mathrm{C}$ overnight. The mixture was separated by column chromatography $\left(\mathrm{SiO}_{2}, \mathrm{CH}_{2} \mathrm{Cl}_{2} /\right.$ hexane, 3:2) providing $133.5 \mathrm{mg}$ (51\% yield) of biszwitterion 2[13] as the fluorescent fraction. The product was recrystallized four times from an $\mathrm{MeCN} / \mathrm{EtOH}$ mixture to obtain $102 \mathrm{mg}$ (39\% yield) of higly purified product: $\left.{ }^{1} \mathrm{H} \mathrm{NMR}\left(500 \mathrm{MHz}, \mathrm{CDCl}_{3}\right) \delta \mathrm{br} \mathrm{m}, 8 \mathrm{H}\right), 0.89(\mathrm{t}, J$ $6.9 \mathrm{~Hz}, 6 \mathrm{H}), 1.25-1.40(\mathrm{~m}, 36 \mathrm{H}), 1.47-1.54(\mathrm{~m}, 4 \mathrm{H}), 1.90$ (quint, J 7.2 Hz, 4H), $4.22(\mathrm{t}, J 6.6 \mathrm{~Hz}, 4 \mathrm{H}), 7.12(\mathrm{~d}, J 7.5$ $\mathrm{Hz}, 4 \mathrm{H}), 9.34$ (d, J $7.5 \mathrm{~Hz}, 4 \mathrm{H}) .{ }^{13} \mathrm{C} N M R\left(125 \mathrm{MHz}, \mathrm{CDCl}_{3}\right) \delta$ 14.2, 22.8, 25.9, 28.7, 29.3, 29.5, 29.6, 29.7, 29.7, 29.8, 70.2, 111.7, 149.6, 168.7; ${ }^{11} \mathrm{~B} N M R\left(160 \mathrm{MHz}, \mathrm{CDCl}_{3}\right) \delta-26.4$ (d, J $\left.120 \mathrm{~Hz}, 8 \mathrm{~B}\right), 16.8$ (s, 2B). Anal. Calcd. for $\mathrm{C}_{36} \mathrm{H}_{70} \mathrm{~B}_{10} \mathrm{~N}_{2} \mathrm{O}_{2}$ : C, 64.43; $\mathrm{H}, 10.51 ; \mathrm{N}, 4.17$. Found: $\mathrm{C}, 64.67 ; \mathrm{H}, 10.27 ; \mathrm{N}, 4.21 \%$. 


\section{Acknowledgements}

This work was supported by the National Science Foundation (DMR-1611250 and XRD facility MRI-1626549) grants. We thank Dr. Rafał Jakubowski and Mr. Jessie Weatherly for technical assistance.

\section{References}

1. Gonzalez, L.; Gimeno, N.; Tejedor, R. M.; Polo, V.; Ros, M. B.; Uriel, S.; Serrano, J. L. Chem. Mater. 2013, 25, 4503-4510.

https://doi.org/10.1021/cm401849f

2. Deschenaux, R.; Donnio, B.; Rheinwald, G.; Stauffer, F.; Süss-Fink, G.; Velker, J. J. Chem. Soc., Dalton Trans. 1997, 4351-4355.

https://doi.org/10.1039/a704712f

3. Abdullah, N.; Mohd Said, S.; Halid, Y. Y.; Megat Hasnan, M. M. I.; Sharmin, N.; Mat Hussin, S. A.; Nik

Ibrahim, N. M. J.; Nordin, A. R.; Safiin, N. A.; Anuar, N. S. J. Coord. Chem. 2016, 69, 2954-2971.

https://doi.org/10.1080/00958972.2016.1221504

4. Abdullah, N.; Sharmin, N.; Ozair, L. N.; Nordin, A. R.; Mohd Nasir, W. S. N.; Mohamadin, M. I. J. Coord.

Chem. 2015, 68, 1347-1360.

https://doi.org/10.1080/00958972.2015.1016428

5. Lin, H.-C.; Shiaw, J.-M.; Liu, R.-C.; Tsai, C.; Tso, H.-H. Liq. Cryst. 1998, 25, 277-283.

https://doi.org/10.1080/026782998206434

6. Kaszynski, P.; Huang, J.; Jenkins, G. S.; Bairamov, K. A.; Lipiak, D. Mol. Cryst. Liq. Cryst. 1995, 260, 315-332. https://doi.org/10.1080/10587259508038705

7. Jankowiak, A.; Baliński, A.; Harvey, J. E.; Mason, K.; Januszko, A.; Kaszyński, P.; Young, V. G., Jr.; Persoons, A. J. Mater. Chem. C 2013, 1, 1144-1159.

https://doi.org/10.1039/C2TC00547F

8. Ringstrand, B.; Kaszynski, P. J. Mater. Chem. 2010, 20, 9613-9615.

https://doi.org/10.1039/c0jm02876b

9. Pecyna, J.; Denicola, R. P.; Gray, H. M.; Ringstrand, B.; Kaszynski, P. Liq. Cryst. 2014, 41, 1188-1198.

https://doi.org/10.1080/02678292.2014.911371

10. Ali, M. O.; Pociecha, D.; Wojciechowski, J.; Novozhilova, I.; Friedli, A. C.; Kaszyński, P. J. Organomet. Chem. 2018, 865, 226-233.

https://doi.org/10.1016/j.jorganchem.2018.04.003

11. Pecyna, J.; Ringstrand, B.; Domagała, S.; Kaszyński, P.; Woźniak, K. Inorg. Chem. 2014, 53, 12617-12626. https://doi.org/10.1021/ic502265g

12. Lu, J.-T.; Lee, C.-K.; Lin, I. J. B. Soft Matter 2011, 7, 3491-3501.

https://doi.org/10.1039/c0sm01376e

13. Ringstrand, B.; Monobe, H.; Kaszynski, P. J. Mater. Chem. 2009, 19, 4805-4812.

https://doi.org/10.1039/b905457j

14. Jankowiak, A.; Sivaramamoorthy, A.; Pociecha, D.; Kaszyński, P. RSC Adv. 2014, 4, 53907-53914.

https://doi.org/10.1039/C4RA06502F 
15. Ringstrand, B.; Jankowiak, A.; Johnson, L. E.; Pociecha, D.; Kaszynski, P.; Pociecha, D.; Gorecka, E. J. Mater. Chem. 2012, 22, 4874-4880.

https://doi.org/10.1039/c2jm15448j

16. Zych, D.; Kurpanik, A.; Slodek, A.; Maroń, A.; Pająk, M.; Szafraniec-Gorol, G.; Matussek, M.; Krompiec, S.; Schab-Balcerzak, E.; Kotowicz, S.; Siwy, M.; Smolarek, K.; Maćkowski, S.; Danikiewicz, W. Chem. Eur. J. 2017, 23, 15746-15758.

https://doi.org/10.1002/chem.201703324

17. Hay, D. A.; Rogers, C. M.; Fedorov, O.; Tallant, C.; Martin, S.; Monteiro, O. P.; Müller, S.; Knapp, S.; Schofield, C. J.; Brennan, P. E. MedChemComm 2015, 6, 1381-1386.

https://doi.org/10.1039/C5MD00152H

18. Chen, P.; Chaikuad, A.; Bamborough, P.; Bantscheff, M.; Bountra, C.; Chung, C.-w.; Fedorov, O.; Grandi, P.; Jung, D.; Lesniak, R.; Lindon, M.; Müller, S.; Philpott, M.; Prinjha, R.; Rogers, C.; Selenski, C.; Tallant, C.; Werner, T.; Willson, T. M.; Knapp, S.; Drewry, D. H. J. Med. Chem. 2016, 59, 1410-1424.

https://doi.org/10.1021/acs.jmedchem.5b00209

19. Renshaw, R. R.; Conn, R. C. J. Am. Chem. Soc. 1937, 59, 297-301.

https://doi.org/10.1021/ja01281a021

20. Blight, B. A.; Wisner, J. A.; Jennings, M. C. Inorg. Chem. 2009, 48, 1920-1927.

https://doi.org/10.1021/ic801725u

21. Yin, S.; Sun, H.; Yan, Y.; Zhang, H.; Li, W.; Wu, L. J. Colloid Interfac. Sci. 2011, 361, 548-555. https://doi.org/10.1016/j.jcis.2011.06.006

22. Alea-Reyes, M. E.; González, A.; Calpena, A. C.; Ramos-López, D.; de Lapuente, J.; Pérez-García, L. J. Colloid Interfac. Sci. 2017, 502, 172-183.

https://doi.org/10.1016/i.jcis.2017.04.064

23. Schmid, G. H.; Wolkoff, A. W. Can. J. Chem. 1972, 50, 1181-1187.

https://doi.org/10.1139/v72-185

24. Maeda, C.; Kamada, T.; Aratani, N.; Sasamori, T.; Tokitoh, N.; Osuka, A. Chem. Eur. J. 2009, 15, 9681-9684. https://doi.org/10.1002/chem.200901475

25. Alcalde, E.; Pérez-García, L.; Dinarés, I.; Frigola, J. J. Org. Chem. 1991, 56, 6516-6521. https://doi.org/10.1021/jo00023a013

26. Born, J. L.; Hadley, W. M. J. Pharm. Sci. 1980, 69, 465-466.

https://doi.org/10.1002/jps.2600690428

27. Born, J. L.; Hadley, W. M. Proc. West. Pharmacol. Soc. 1980, 23, 259-262.

28. Butler, D. E.; Bass, P.; Nordin, I. C.; Hauck, F. P., Jr.; L'Italien, Y. J. J. Med. Chem. 1971, 14, 575-579. https://doi.org/10.1021/jm00289a005

29. Koenigs, E.; Neumann, L. Chem. Ber. 1915, 48, 956-963.

https://doi.org/10.1002/cber.191504801130

30. Abou-Shehada, S.; Teasdale, M. C.; Bull, S. D.; Wade, C. E.; Williams, J. M. J. ChemSusChem 2015, 8, 10831087.

https://doi.org/10.1002/cssc.201403154

31. Yang, Q.-Y.; Lehn, J.-M. Angew. Chem. Int. Ed. 2014, 53, 4572-4577.

https://doi.org/10.1002/anie.201400155

32. Koenigs, E.; Greiner, H. Chem. Ber. 1931, 64, 1049-1056.

https://doi.org/10.1002/cber.19310640518 
33. Vompe, A. F.; Monich, N. V.; Meskhi, L. M. Russ. J. Org. Chem. 1974, 10, 1301-1306.

34. For details see Supplementary Material.

35. Wojciechowski, J.; Kaszynski, P.; Friedli, A. C. CCDC \# 1828912.

36. Fulmer, G. R.; Miller, A. J. M.; Sherden, N. H.; Gottlieb, H. E.; Nudelman, A.; Stoltz, B. M.; Bercaw, J. E.; Goldberg, K. I. Organometallics 2010, 29, 2176-2179.

https://doi.org/10.1021/om100106e

37. Kaszynski, P.; Ringstrand, B. Angew. Chem. Int. Ed. 2015, 54, 6576-6581.

https://doi.org/10.1002/anie.201411858 